\title{
On The Origins of Risk-Taking in Financial Markets
}

SANDRA E. BLACK | PAUL J. DEVEREUX | PETTER LUNDBORG | KAVEH MAJLESI

KNUT WICKSELL WORKING PAPER 2015:7

\section{Working papers}

Editor: F. Lundtofte The Knut Wicksell Centre for Financial Studies

Lund University School of Economics and Management 



\title{
On The Origins of Risk-Taking in Financial Markets ${ }^{1}$
}

\author{
Sandra E. Black \\ Department of Economics \\ University of Texas, Austin \\ NHH, IZA and NBER \\ sblack@austin.utexas.edu \\ Paul J. Devereux \\ School of Economics and Geary Institute, University College Dublin \\ CEPR and IZA \\ devereux@ucd.ie \\ Petter Lundborg \\ Department of Economics, Lund University \\ Centre for Economic Demography \\ Knut Wicksell Centre for Financial Studies, IZA \\ petter.lundborg@nek.lu.se \\ Kaveh Majlesi \\ Department of Economics, Lund University \\ Knut Wicksell Centre for Financial Studies \\ kaveh.majlesi@nek.lu.se
}

August 2015

\begin{abstract}
Risk-taking in financial markets is highly correlated between parents and their children; however, little is known about the extent to which these relationships are genetic or determined by environmental factors. We use data on stock market participation of Swedish adoptees and relate this to the investment behavior of both their biological and adoptive parents. We find that stock market participation of parents increases that of children by about $34 \%$ and that both pre-birth and post-birth factors are important. However, once we condition on having positive financial wealth, we find that nurture has a much stronger influence on risk-taking by children, and the evidence of a relationship between stock-holding of biological parents and their adoptive children becomes weaker. We find similar results when we study the share of financial wealth that is invested in stocks. This suggests that a substantial proportion of the transmission of risk behavior from parents to children is environmentally determined.

\footnotetext{
1 The data used in this paper come from the Swedish Interdisciplinary Panel (SIP) administered at the Centre for Economic Demography, Lund University, Sweden. This paper has benefited from the valuable comments of participants at seminars at the Copenhagen Business School, Lund University, Southern Denmark University, The University of Texas at Austin, UC Davis, and conference participants at the ABL Conference, ESPE, NBER Summer Institute, and SoLE/EALE. All errors are our own.
} 


\section{Introduction}

Parents who hold riskier financial portfolios have children who themselves hold riskier financial portfolios. In the United States, children with a parent who owned stocks in 1984 were 16 percentage points more likely to own stocks themselves in 1999 (Charles and Hurst, 2003). In Sweden, children with at least one parent who owned stocks in 2000 were 22 percentage points more likely to own stocks themselves in that same year. The intergenerational persistence of risky market participation and its determinants are important, first and foremost, because of their welfare implications; historically, risky market investment has had a higher return compared to safer financial assets such as bonds and money market funds. Thus, to the extent that risk-taking behavior is correlated with wealth, these behaviors can exacerbate or mitigate wealth inequality over time.

But why is financial risk-taking correlated across generations? Does this have to do with pre-birth characteristics that are correlated across generations (such as genetic predisposition towards risk-taking), or is it that children learn from parents, and risktaking behavior is acquired over one's lifetime? ${ }^{2}$ Is it nature or is it nurture? To provide insight into this question, we take advantage of a unique feature of the Swedish adoption system whereby we observe both the biological and adoptive parents of adopted children. We use administrative data on the portfolio choices of a large sample of adopted children born between 1950 and 1980 merged with similar information for their biological and adoptive parents--as well as corresponding data on own-birth children. We disentangle the role of nature versus nurture in the intergenerational transmission of risky behavior by looking at how the risk taking behavior of adoptive children is related to that of both their

\footnotetext{
${ }^{2}$ Recent research in gene-mapping suggests that specific genes are associated with risk attitudes and risktaking behavior. See, for example, Kuhnen and Chiao (2009) and Dreber et al. (2009).
} 
biological and adoptive parents. Adoption allows us to examine the effects of environmental factors in a situation where children have no genetic relationship with their (adoptive) parents. ${ }^{3}$

Our paper relates to an active literature that documents intergenerational correlations in both risk preferences and asset allocations. Charles and Hurst (2003), Hryshko, Luengo-Prado, and Sorensen (2011), Dohmen, et al. (2012), and Kimball, Sahm, and Shapiro (2009) all document similarities in self-reported attitudes towards risk across generations. The same tendency in the choice of assets across generations has been documented by Chiteji and Stafford (1999) and Charles and Hurst (2003), among others.

To distinguish between genetic and environmental determinants of risky financial behavior, the literature has focused on twins studies. ${ }^{4}$ Cesarini et al. (2010) and Barnea, Cronqvist, and Siegel (2010) both use differences between identical and fraternal twins to decompose the cross-sectional variation in investor behavior. Interestingly, they find very little, if any, role for shared environmental factors, suggesting that parental influences on children operate predominantly through genetic channels. However, the twin approach is fundamentally different from what we do with adoption data in that it decomposes the total variation in asset allocation into genetic and environmental factors; it does so by

\footnotetext{
${ }^{3}$ Adoption studies have been widely used by economists in other contexts to determine the relative roles of genes and environment in influencing economic behavior. Important adoption studies include Plug and Vijverberg (2003), Plug (2004), and Sacerdote (2007). Recent studies using Swedish data include the seminal study of Björklund, Lindahl, and Plug (2006) who studied educational attainment and earnings. Since then, the Swedish data have been used to study voting (Cesarini, Johannesson, and Oskarsson, 2012), crime (Hjalmarsson and Lindquist, 2013), entrepreneurship (Lindquist, Sol, and Van Praag, 2015), and health (Lindahl et al. 2015). These studies have found evidence that both characteristics of biological and adoptive parents are predictive of child outcomes.

${ }^{4}$ Also, Dohmen et al. (2012) use data from the German Socio-Economic Panel Study (SOEP) and find evidence of environmental influences in the determination of child risk attitudes net of parental risk attitudes, suggesting that both nature and nurture play a role.
} 
making relatively strong assumptions about the similarities in environment and genetics across fraternal and identical twins. Our approach studies the intergenerational association and relies on an entirely different set of assumptions. Because of the differences in the methodologies and goals, the approaches can be seen as complements rather than substitutes. ${ }^{5}$

We find evidence for important effects of both genes and environment on the decision to hold stocks, implying a role for both genetic transmission of risk attitudes as well as environmental influences. However, once we condition on positive financial wealth, which is correlated with both biological and adoptive parents risk-taking, we find that nurture has a much stronger influence on risk-taking by children. We find similar results when we study the share of financial wealth that is invested in stocks. Importantly, these results do not appear to be driven by the amount of parental wealth or even children's wealth holdings, education, or income, once we condition on positive financial wealth holding of children. These conclusions are robust to a variety of robustness and specification checks.

The structure of the paper is as follows. In the next section, we discuss the institutional background both in terms of financial markets and the adoption process. In section 3, we outline the econometric methodology and, in section 4, we describe the data. Section 5 has estimates for the intergenerational transmission of stock-holding, including specifications that allow for interactions between nature and nurture and differences by the gender of the child. In Section 6, we present a variety of robustness and specification tests, including testing the sensitivity of our results to the potential non-random

\footnotetext{
${ }^{5}$ We discuss how our estimates compare to those from twin studies in the conclusion.
} 
assignment of children to adoptive parents and the choice of years of data. Section 7 discusses the external validity of our results, and Section 8 concludes.

\section{Institutional Background}

\section{A. Financial Wealth in Sweden}

Stock market participation rates are higher in Sweden than in many other countries such as the United States (Guiso, Haliassos, and Jappelli, 2001). In addition, a large proportion of financial wealth is held outside of pension funds: Non-retirement wealth accounts for almost 84 percent of aggregate household financial wealth (Calvet, Campbell, and Sodini 2007), and it is this form of wealth that is the focus of our study. However, it is important to understand the nature of the pension system due to its potential effect on savings.

Relative to countries such as the U.S., Sweden's pension system would be considered quite generous. Sweden has a mix of public and private pension schemes, and individuals are allocated to different pension systems depending on the public or private sector affiliation and year of birth of the individual. The longer one works, the higher the pension one receives. The retirement age is flexible and individuals can claim retirement benefits beginning at age $61 .^{6}$

\footnotetext{
${ }^{6}$ In 2000, when we measure asset allocation, the public pension system almost entirely consisted of a national pension plan financed on a pay-as-you-go basis (an individual account system known as the Premium Pension System (PPS) was introduced in 1999 but, because these funds were so new, investment in the PPS funds was very low when we are measuring asset allocation). In addition, most people receive an occupational pension from their employer. According to the Swedish Pensions Agency, about $90 \%$ of employees receive some pension benefits from their employer as a condition of employment. On average, around $4.5 \%$ of the employee's salary is put into employer provided schemes (Thörnqvist and Vardardottir, 2014). Swedish residents also have tax incentives to invest in private pension savings that are only accessible after retirement. However, as mentioned earlier, individuals still hold a substantial fraction of their wealth in non-retirement wealth. There is also a guaranteed pension for those who have had little or no income from work, and the size of this guaranteed pension is based on how long the person has lived in
} 
Because we examine both male and female investment behavior separately, it is important to understand whether there are incentives to transfer wealth holdings from one spouse to another. There do not appear to be any such incentives. In the event of a divorce, in the absence of a prenuptial agreement, all assets are split equally among spouses. For wealth tax purposes, the value of jointly owned assets was split evenly between the two tax filers. Thus, there were no incentives for husbands and wives to strategically allocate assets between themselves in order to reduce their wealth tax bill.

Finally, people who face greater labor income risk may be less likely to choose risky financial portfolios. Consequently, the unemployment insurance system could potentially affect individuals' risk-taking behavior in financial markets; a more generous system could create an incentive to take more risk with one's portfolio. In 2000, while the formal replacement rate was at 80 percent of wages, the effective replacement rate taking earnings-ceilings into account was around 65 percent (Carling, Holmlund, and Vejsiu 2001). ${ }^{7}$ Because of this, it is difficult to imagine that high risky market participation in Sweden compared to many other countries can be explained by the "generous" unemployment insurance system.

\section{B. The Adoption System ${ }^{8}$}

The adoptees we study were born between 1950 and 1980. During this period,

Sweden. In 2000, the maximum guaranteed pension, which applies to those who have lived in Sweden for at least 40 years, is 2394 SEK per month (\$254) before taxes for those who are married, and 2928 SEK per month (\$311) for a single person. A tax rate of 30 percent is then applied.

${ }^{7}$ There is an earnings ceiling above which no additional benefits are paid. In 1996, it was estimated that 75 percent of employees had monthly earnings exceeding the ceiling (Bharadwaj et al. 2014).

${ }^{8}$ See Bjorklund, Lindahl, and Plug (2006) and Lindquist, Sol, and Van Praag (2015) for more details. 
private adoptions were illegal, so all adoptions went through the state. The state collected information on both the biological and adoptive parents; while it only required information on the biological mother, in many cases, social workers were also able to identify the biological fathers. About $80 \%$ of children were adopted in their first year of life. $^{9}$

In order to adopt a child, a family had to satisfy certain requirements. The adoptive parents had to be married and be at least 25 years old, have appropriate housing, and be free of tuberculosis and sexually transmitted diseases. The adoptive father was required to have a steady income and the adoptive mother was required to be able to stay home with the child for a certain period of time. ${ }^{10}$ Overall, the adoption criteria meant that the adoptive parents were positively selected relative to the general population.

While matching of children to adoptive parents was at the discretion of the caseworkers, the evidence from that period suggests that social authorities were not able to systematically match babies to families based on family and child characteristics (see Lindquist, Sol, and Van Praag 2015 for more details). ${ }^{11}$ However, we will examine this issue in more detail later.

\footnotetext{
${ }^{9}$ Upon turning 18, an adopted child has the legal right to obtain information from public authorities about the identity of his or her biological parents (Socialstyrelsen 2014). However, according to Swedish law, there is no legal requirement for parents to inform adopted children that they are adopted (SOU 2009).

${ }^{10}$ Prior to 1974 , there was no parental leave to care for adopted children. In 1974, the modern Swedish parental leave system was introduced; in this system, parents had the right to a total of 6 months of paid parental leave that could be divided among the parents as preferred. The system gave equal rights to ownbirth children and adopted children (SOU 1978). It replaced the older "moderskapsersättning" system that was introduced in 1955 and that gave mothers the right to 3 months of paid leave (SOU 1954).

${ }^{11}$ While children could be adopted by relatives, in practice this was very rare. Nordlöf (2001) reports that of 1186 adoptions taking place in Stockholm for children born between 1960 and 1973, in only 4 cases was an adoptive parent related to the child.
} 


\section{Empirical Strategy}

Adoption studies have been widely used by economists in other contexts to determine the relative roles of genes and environment in influencing economic behavior. Much of this research has incorporated information on outcomes of adoptive parents but not on the biological parents of adopted children; thus, it does not compare the relative effects on adopted children of the behaviors or outcomes of biological and adoptive parents. ${ }^{12}$ Recent studies using Swedish data have been able to make this comparison by taking advantage of the availability of data on both biological and adoptive parents. These include the seminal study of Björklund, Lindahl, and Plug (2006) who studied educational attainment and earnings. Since then, the Swedish data have been used to study voting (Cesarini, Johannesson, and Oskarsson, 2014), crime (Hjalmarsson and Lindquist, 2013), entrepreneurship (Lindquist, Sol, and Van Praag, 2015), and health (Lindahl et al. 2015). These studies have found evidence that both characteristics of biological and adoptive parents are predictive of child outcomes.

Our primary specification uses data on adoptees to relate stock market participation of an adoptee to the stock market participation of both his/her biological and adoptive parents. We estimate the following equation:

$P_{i j}=\beta_{0}+\beta_{1} P_{i m}+\beta_{2} P_{i f}+\beta_{3} P_{j m}+\beta_{4} P_{j f}+X \beta_{5}+\epsilon_{i j}$

where $P$, our main variable of interest, is an indicator of whether an individual has stocks in their portfolio, $i$ indexes the biological family, $j$ indexes the adoptive family, $m$ refers

\footnotetext{
${ }^{12}$ While working on this paper, we became aware of concurrent work by Fagereng, Mogstad, and Rønning (2015), who use Korean adoptees in Norway to determine the effect of environment on child wealth and asset allocation. The authors find a substantial role for environment. A key advantage of this work is that the assignment of children to families is arguably random. A key limitation, however, is that they do not observe characteristics of the biological family. We view this paper as a complement to our own work. More broadly, see Sacerdote (2010) for a survey of this literature.
} 
to mother and $f$ refers to father, and $X$ refers to the set of control variables. Because asset allocation may vary by age, these include year-of-birth dummies for both parents and children, along with a dummy variable for the gender of the child. We estimate linear probability models but have verified that the marginal effects are very similar when a probit model is used.

A key assumption in our empirical strategy is that adoptees are randomly assigned to adoptive families at birth. Under this assumption, the coefficients on stock market participation of biological parents provide an estimate of the effect of pre-birth factors and the coefficients on stock market participation of adoptive parents provide an estimate of the effects of post-birth factors. We will test this assumption in a variety of ways; while the assumption is not strictly true in our data, we provide evidence that suggests that violations of the assumption do not have meaningful effects on our estimates.

\section{Data}

We begin with merged administrative data containing information on all Swedish citizens born between 1950 and 1980, including information on educational attainment, county of residence, basic demographic information, and detailed wealth data. ${ }^{13}$ To this we merge the Swedish multigenerational register, which contains information on both

\footnotetext{
${ }^{13}$ The register contains information on highest educational degree completed, which we use to impute years of schooling. We follow Holmlund et al. (2011) and impute years of schooling in the following way: 7 for (old) primary school, 9 for (new) compulsory schooling, 9.5 for (old) post-primary school (realskola), 11 for short high school, 12 for long high school, 14 for short university, 15.5 for long university, and 19 for a $\mathrm{PhD}$ university education. Since the education register does not distinguish between junior-secondary school (realskola) of different lengths ( 9 or 10 years), it is coded as 9.5 years. For similar reasons, long university is coded as 15.5 years of schooling.
} 
biological and adoptive parents for adopted children, and enables us to link children born 1980 or earlier to their parents.

For data on asset allocation, we predominantly rely on the Swedish Wealth Data (Förmögenhetsregistret). These data were collected by the government's statistical agency, Statistics Sweden, for tax purposes between 1999 and 2007, at which point the wealth tax was abolished. ${ }^{14}$ For the years 1999 to 2006, the data include all financial assets held outside retirement accounts at the end of a tax year, December 31st, reported by a variety of different sources, including the Swedish Tax Agency, welfare agencies, and the private sector. Financial institutions provided information to the tax agency on their customers' security investments and dividends, interest paid or received, and deposits, including nontaxable securities and securities owned by investors, even for persons below the wealth tax threshold. Because the information is based on statements from financial institutions, it is likely to have very little measurement error and, because the entire population is observed, selection bias is not a problem.

From this, we observe the aggregate value of bank accounts, mutual funds, stocks, options, bonds, and capital endowment insurance as well as total financial assets and total assets. ${ }^{15}$ We analyze equity market participation, and the extent of it, using outcome

\footnotetext{
${ }^{14}$ During this time period, the wealth tax was paid on all the assets of the household, including real estate and financial securities, with the exception of private businesses and shares in small public businesses (Calvet, Campbell, and Sodini 2007) and, in year 2000, was levied at a rate of 1.5 percent on net household wealth exceeding SEK 900,000. The Swedish krona traded at $\$ 0.106$ at the end of 2000, so this threshold corresponds to $\$ 95,400$. After 2000 , the tax threshold was raised to SEK 1,500,000 for married couples and non-married cohabitating couples with common children and 1,000,000 for single taxpayers. In 2002 the threshold rose again, this time to SEK 2,000,000 for married couples and non-married cohabitating couples and 1,500,000 for single taxpayers. In 2005 the threshold rose once more but this time only for married couples and cohabitating couples, this time to SEK 3,000,000.

${ }^{15}$ Small bank accounts were not reported by banks to the Swedish Tax Agency unless there was more than 100 SEK (about \$10) in interest during the year. However, Statistics Sweden estimates that 98\% of the total money in bank accounts is included in the data.
} 
variables constructed in year 2000, although we have tested the sensitivity of our conclusions to this choice and have found them to be quite robust. ${ }^{16}$

Our primary measure of equity market participation is an indicator variable for whether the individual owns stocks directly - we refer to this as stock market participation or direct equity participation. However, we also study the share of financial wealth that is invested in stocks - we refer to this as the stock share or risky share. As a robustness check, we also report estimates using a broader measure of risk taking that includes participation through either direct stock holding or mutual funds with a stock component. $^{17}$

We use data from the Income Register to measure income for our sample. The register includes income beginning in 1968. Our measure of income includes earnings from employed labor as well as self-employment income and taxable benefits. The variable we use is the log of average (deflated) labor income between 1980 and 2000. In the few cases where labor income is zero in all years, we set the log to zero.

Our sample includes children born in 1950 or later with all applicable parents alive in 2000 and for whom we have information on schooling, earnings, and wealth. ${ }^{18}$ We have information on over two million children who are raised by their biological parents and 3275 adopted children who have data available for both biological and

\footnotetext{
${ }^{16}$ We have run all the regressions with wealth data from 1999 and 2001 and the results are identical. We also show later in the paper that the estimates are similar when we use data from 1999 for parents and 2006 for children.

${ }^{17}$ This includes holdings of mutual funds that only include stocks but also includes mutual funds that have a mixture of stocks and other financial instruments such as cash or bonds.

${ }^{18}$ Because of changing access to contraception and abortion in the later 1960s and early 1970s, there is some concern that children born and adopted after 1970 could be different. However, as we show later, results using only children born before 1970 are very similar.
} 
adoptive mothers and fathers. ${ }^{19}$

We report descriptive statistics for our sample in Table 1. The top panel has means for children, both biological and adoptive. In 2000, when their assets and education are measured, the average child age is 32.5 for biological children and 35 for adoptive children. Biological children have half a year more education on average and their probability of holding stocks is higher ( $26 \%$ to $23 \%$ ). However, adopted children have higher financial assets.

The second panel has means for biological parents, both parents who raised their own biological children and parents who gave their children up for adoption. There are large differences in the characteristics of these two types of biological parents with the biological parents of adoptees having much less wealth and lower years of schooling.

Finally, the bottom panel has descriptive statistics for adoptive parents. For adopted children, adoptive parents are older, wealthier, better educated, and more likely to hold stocks and risky assets than the child's biological parents. When compared to biological parents who raise their own children, adoptive parents also seem positively selected, but the differences here are much smaller.

\section{Results}

Table 2a provides estimates of equation (1) for the sample of adopted children with an indicator for stock market participation as the dependent variable. ${ }^{20}$ In column (1),

\footnotetext{
${ }^{19}$ We later test the sensitivity of our conclusions to the restriction that we observe both biological mothers and fathers of adopted children and find the results to be quite consistent.

${ }^{20}$ Because there can be multiple adoptive children in a family, we cluster the standard errors at the adoptive family level.
} 
we include dummies for stock market participation of both biological and both adoptive parents. All coefficients are statistically significant, but the coefficients on adoptive parents are larger than those on biological parents, suggesting that pre-birth factors (including genes) have a smaller influence on risk taking in financial markets than do environmental factors. ${ }^{21}$

In column (1) of Table 2a, we included all parents and children irrespective of whether they have positive financial wealth. However, individuals without financial wealth cannot invest in stocks, so for those individuals without financial wealth, we may not be observing their true risk preferences. As a result, we next consider what happens to our estimates when we condition on having positive financial wealth—first of the parents and then of the children.

In column (2) of Table 2a, we add indicator variables for whether each type of parent has positive financial wealth (4 indicator variables in total). Now the coefficients on risky asset holding reveal the effect of parental stock holding conditional on parents having positive financial wealth. If the coefficients change substantially, this suggests that the relationship we are observing may in fact be driven by the effect of parental financial wealth (or other variables correlated with parental financial wealth) on the risktaking of children instead of the effect of parental risk taking itself. It is important to note that the adoptive coefficients remain positive and statistically significant and similar in size to those in column (1), suggesting that very little of the relationship with adoptive parents can be explained by positive parental financial wealth holding. However, the

\footnotetext{
${ }^{21}$ If we exclude risk taking of mothers or of fathers, the coefficients increase somewhat when the risky holdings of the other spouse is omitted, presumably because of assortative mating.
} 
biological coefficients fall somewhat and the effect of the biological father is now no longer statistically significant.

Next, we condition on children having positive financial wealth; in this case, we are considering the relationship between child and parent risk-taking conditional on them both having positive financial wealth (and thus the opportunity to hold risky assets). However, these results are quite speculative, as children's positive financial wealth may be endogenous to parent's risk-taking behaviors (both biological and adoptive). ${ }^{22}$

In column (3) we estimate the stock-holding regression, conditioning on the indicators for positive parental financial wealth and including only children who have positive financial wealth. This reduces the sample size from 3275 to 1986 . Interestingly, the relative magnitude of the adoptive coefficients increases relative to the biological coefficients. So, conditional on parents and children having positive financial wealth, there is less evidence that the risk-taking of biological parents affects child behavior, suggesting a limited role for genetically determined risk preferences or ability.

The relationship between portfolio choices of parents and their adoptive children could reflect a direct causal effect of parental stock-holding or environmental transmission of risk preferences. However, it is also possible that parental stock-holding is proxying for other omitted parental characteristics such as parental wealth, income, or education, and it is these characteristics that directly affect the behavior of the child. To test this possibility, we control for all these characteristics of the adoptive and biological

\footnotetext{
${ }^{22}$ In Appendix Table 1 we examine whether the child has positive financial wealth as a function of parental characteristics. In Column 1, we see that there is a clear positive relationship between stock-holding of all four types of parents and the child having positive financial wealth. When we control for whether parents have positive financial wealth (Column 2), we still find positive effects but they are smaller, particularly for biological parents. We have also verified that, if we control for the level of parental financial wealth, the biological risk-taking coefficients become very small and statistically insignificant. Columns 3 and 4 present comparable results for the children raised by their biological parents for comparison.
} 
parents and see whether coefficient on parents' stock-holding declines. These estimates are in Column (4) of Table 2a. Comparing the estimates to those in column (3), we see that the addition of parental characteristics reduces the coefficients but not by a lot.

One other possibility is that transmission of risk preferences occurs because parents with risky portfolios are wealthier and invest more in their children's human capital. $^{23}$ To assess this possible mechanism, we add a control for child education. We also add controls for child earnings and child wealth to see whether these reflect plausible mechanisms. The estimates (in column (5) of Table $2 \mathrm{a}$ ) are almost identical to those in column (4). While this type of analysis can only be suggestive due to the endogeneity of the child characteristics, it suggests that these may not be important intermediate variables in the intergenerational transmission of stock-holding. ${ }^{24}$

An alternative measure of risk-taking is the stock share -- the proportion of financial wealth invested in stocks. We study the intergenerational relationships in this variable in columns (6) and (7). In column (6), we restrict the sample to children with positive financial wealth and, in column (7), we further restrict to children who hold some stocks. Analogously, the controls in column (6) include indicators for whether parents have positive financial wealth and those in column (7) include indicators for whether parents hold stocks. In both columns, we find that the intergenerational relationships are only evident for adoptive parents. The effects are quite large - an increase in the stock share of 0.1 for an adoptive mother (father) increases the stock share

\footnotetext{
${ }^{23}$ In earlier work, we used exogenous variation in education due to compulsory schooling laws to show that there is a positive effect of educational attainment on risky market participation of men (Black et al. 2015).

${ }^{24}$ Unlike Charles and Hurst (2003) who find the intergenerational correlation in stock ownership can be explained away once parent and child incomes are controlled for, we do not find such an effect. An advantage of this study compared to Charles and Hurst (2003) is that we have earnings data for a longer period of time.
} 
of the adoptive child by $0.03(0.02)$.

How can we interpret these results? In a standard portfolio-choice model (assuming constant relative risk aversion (CRRA) and independently and identically distributed returns), the risk preference parameter for an individual is proportional to the share that the individual invests in equities. So, our finding that intergenerational correlations in the stock shares are only evident for adoptive parents could be interpreted, in the context of this model, as suggesting that intergenerational correlations in risk attitudes may be environmentally rather than genetically determined.

Table $2 \mathrm{~b}$ has analogous results for own-birth children for comparison. As has been documented in the literature, the magnitudes of the intergenerational correlations are quite substantial. About $26 \%$ of own-birth children invest in stocks. The effects for ownbirth children imply that having a father who invests in these assets increases child participation by .14 or about $54 \%$ of the mean. The equivalent figure for mothers is even larger at $73 \%$. Consistent with other papers using different outcome variables, we find that the effect of parent asset allocation on that of own birth children is approximately equal to the sum of the biological and adoptive effects for adoptive children. For example, comparing column (1) of Table $2 a$ to column (1) of Table $2 b$, the sum of the coefficients is .42 in the former and .34 in the latter. This finding suggests that the total overall intergenerational transmission through nature and nurture may be largely unaffected by the adoption itself. 


\section{Household Level Analysis}

In the analysis so far, we have studied mother and father stock-holding separately. However, it is plausible that adoptive parents make joint decisions about their portfolio allocation. Therefore, in Table 3, we report estimates where we combine mothers and fathers. For stock holding, the variable now becomes 1 if either parent holds stocks and zero otherwise; for the stock share, the variable becomes the proportion of the total financial wealth of the mother and father that is invested in stocks. At this aggregate level, the findings very clearly show that environmental factors are more important than biological and, once there are controls for parents and children having positive financial wealth, the evidence suggests intergenerational correlations in risk-taking are predominantly due to nurture rather than nature.

\section{Gender Differences}

There are a number of reasons we might expect the relationship between parents' and child's risky financial behavior to vary by gender. First, it is well documented that attitudes towards risk differ between men and women. ${ }^{25}$ Also, it is plausible that children are influenced by their adoptive parents' risk attitudes as a result of information sharing or role modeling, and that these effects differ systematically by gender - for example, children may be more influenced by the adoptive parent of the same sex. Therefore, in Tables $4 \mathrm{a}$ and $4 \mathrm{~b}$, we split the sample by child gender. The coefficient estimates suggest girls are more influenced by their adoptive mother and boys by their adoptive father

\footnotetext{
${ }^{25}$ See, Eckel and Grossman (2008) for a survey of the literature. Also, using data for over 35,000 households from a large discount brokerage, Barber and Odean (2001) analyze the investment behavior of men and women from 1991 to 1997 and document that men trade 45 percent more than women.
} 
(although the differences are only statistically significant for girls). While this evidence is only speculative, it does suggest that role-model effects may be part of the explanation for the patterns we observe.

\section{Interaction between Nature and Nurture}

We have thus far assumed that the effects of biological and adoptive parents are independent of each other. However, this may be an oversimplification if the genetic component interacts with the environmental component, one building on the other. ${ }^{26} \mathrm{We}$ present the results when we allow for an interaction between biological and adoptive parents in Table 5. In each column, we allow an interaction between the effects of biological and adoptive mothers and an equivalent interaction for fathers. In most of the specifications, the interaction terms are small and statistically insignificant, suggesting that those with genetic factors "suitable" for risky market participation do not necessarily benefit more from an environment in which a parent invests in risky markets.

\section{An Alternative Measure of Risky Assets}

In Table 6, we report estimates where we use a broader definition of risky asset holding that includes mutual funds with a stock component in addition to stock holdings. Note that the included mutual funds may also include less risky assets such as bonds and cash. The results are qualitatively similar to those for stock-holding. Risky-holding of adoptive parents is more predictive of risky-holding of children than is risky-holding of

\footnotetext{
${ }^{26}$ There are mixed findings in the literature about these types of interactions - Bjorklund, Lindahl, and Plug (2006) finds evidence of these interactions for mothers' education and fathers' earnings but Lindquist, Sol, van Praag (2015) finds no evidence for these interactions when studying entrepreneurship.
} 
biological parents. Again, it is notable that, once one controls for parents and children having positive financial wealth, there is no evidence for any biological effects. When we look at the risky share, there is also no evidence that child behavior is related to that of their biological parents. So, the conclusions using this broader measure are very similar to those for stock-holding.

\section{Tests of Model Assumptions and Specification Checks}

Our interpretation of the coefficients above as reflecting the nature versus nurture components of intergenerational correlations in financial risk-taking requires a number of assumptions. One of these is that adoptions occur soon after birth-if this was not the case, the coefficient on biological parents might reflect both nature and nurture, and our estimates would be biased in favor of the nature component. Because we do not observe the timing of the adoption in our data, we cannot test this directly; however, we do know that about $80 \%$ of adoptions occur within the first year after birth, so there is limited postbirth experience of the biological parents for most adoptees in our sample (Björklund, Lindahl, and Plug 2006).

The other important assumption is that adoptees are randomly assigned to adoptive families and we address this next. For parsimony, we only report robustness checks for the specification in column (1) of Tables 2-5. Estimates from the other specifications are similarly robust.

Random Assignment of Adoptees

As noted earlier, adoptees may not be randomly assigned to parents, so the 
question then becomes how this non-random assignment might be affecting our estimates. The primary concern is that coefficient estimates may be biased due to correlations between risk holdings of adoptive (biological) parents and unobserved characteristics of the biological (adoptive) parents that are correlated with child risk holding. While earlier work using similar strategies with Swedish data has demonstrated that this non-random assignment is unlikely to be a problem, we conduct a number of robustness checks to verify this.

If there are correlations between risk holdings of adoptive parents and unobserved characteristics of the biological parents that are correlated with child risk holding, one might expect the coefficients on risk holding of adoptive parents to vary depending on whether risk holding of biological parents is included in the regression. The results when we do this are presented in Table 7. Column (1) of Table 7 shows estimates with just the stock holding variables for the adoptive parents included. In column (2), we add stock holding variables for the biological parents, which is the specification previously reported in column (1) of Table 2a. As we can see in column (2), these coefficients on adoptive parents' stock holding change very little when we include biological parents stock holding behavior, suggesting that the two variables are not highly correlated. As another check for omitted variable bias, we next include a number of other controls for characteristics of the biological parents. Again, if it were the case that the results were driven by selection of adopted parents, then adding further controls for biological parents' characteristics should reduce our coefficients on adoptive parents' stock holding. Column (3) of Table 7 includes risk holdings of adoptive parents and adds controls for schooling, earnings, and wealth of biological parents as proxies for general unobserved 
characteristics of biological parents. Comparing the coefficients on adoptive parent risk holding in column (3) to column (1), the difference is very small. Finally, in column (4), we include both biological risk-taking and the other characteristics of biological parents. The resulting estimates are almost identical to those in column (3). Overall, it appears that our adoptive estimates are unlikely to be significantly biased by non-random assignment.

Columns (5) to (8) of Table 7 carry out the analogous exercise for stock holding for biological parents. In column (5), we only include the stock holding variables for the biological parents and then, in column (6) we add the stock holding behavior of the adoptive parents. Column (7) adds controls for education, income, and wealth of adoptive parents, and column (8) includes both stock holding behavior for adoptive parents as well as their education, income, and wealth. While the coefficients on stock holding of biological parents decrease somewhat in columns (6)-(8) compared to column (5), the differences are not very large. This suggests that non-random assignment of adoptees is unlikely to be a problem and, if anything, will lead to an overstatement of the role of biological parents relative to that of adoptive parents.

\section{Varying When Stock-Holding is Measured}

There are a number of reasons why one might be concerned about the concurrent measuring of stock holding for parents — both biological and adoptive-and children. The first is that there might be reverse causation-- children are influencing their parents' behavior, and not the other way around. While it seems safe to assume that our estimates of biological effects do not suffer from reverse causation since there is likely little contact 
between biological parents and their children, it is possible that the environmental effects could partially reflect the influence of adopted children on their adoptive parents. For example, a risk-loving child could persuade his/her parents to invest in more risky assets. While it is impossible to rule out this mechanism, we can redo the estimation using parental risk-taking in 1999 and child risk-taking in 2006. Because we measure the variables for parents 7 years before the equivalent variables for children, reverse causality is less of an issue than when we measure them contemporaneously. ${ }^{27}$

Table 8 presents these results. As can be seen by comparing Column (1)--our baseline specification using data from 2000 from our earlier specification-to Column (2) - the same specification using data from 1999/2006, estimates are similar to our baseline. $^{28}$

Another potential issue is that biological parents are on average 9 years younger than the adoptive parents in 2000. Given that there may be life-cycle patterns in stock holding behavior, our conclusions may be sensitive to this difference. ${ }^{29}$ To address this, we can measure the stock-holding of adoptive parents in 1999 and biological parents in 2006, thus largely eliminating the age gap at measurement. Columns (3) and (4) of Table 8 report these estimates for child stock-holding measured in 2000 and 2006, respectively. We find that the estimates are quite similar in both cases.

\footnotetext{
${ }^{27}$ Taking this approach also increases the age we observe children's stock holding by 6 years and so allows us to see whether our results are sensitive to child age. Later, in Appendix Table 2, we do a robustness check where we leave out the youngest cohorts.

${ }^{28}$ Furthermore, we have examined whether changes in stock market participation between 1999 and 2006 are correlated for parents and children and found only a tiny relationship. This suggests that parental preferences for risk-taking are unlikely to be influenced by their children's preferences.

${ }^{29}$ Using Norwegian data, Fagereng, Gottlieb, and Guiso (2013) document life cycle patterns in stock market participation and portfolio allocation.
} 


\section{Further Robustness Checks}

While we have attributed the relationship between adoptive parents' behavior and children's decisions to parental behavior and environment, it may be that both parents and children are subject to common influences such as both living in an area in which there is high stock market participation. To examine this, in Column (2) of Appendix Table 2 we add controls for county of residence of both parents and children in $2000 .{ }^{30}$ Conclusions are robust to this specification check.

Thus far, we have also assumed that the relationships we are estimating are constant across cohorts. However, this may not be the case; the introduction of contraception (the Pill) as well as the legalization of abortion occurred in the late 1960s and early 1970s in Sweden; as a result, the characteristics of children being put up for adoption changed over this time period. To investigate this, we estimate our basic specification using the subset of cohorts born by 1970; these results are presented in column (3) of Appendix Table 2. The results are quite robust to the choice of cohorts.

Note that, by restricting to cohorts born by 1970 , we are also excluding children younger than 30 from our sample. In column (4) of Appendix Table 2, we restrict the sample to persons born by 1970 and also measure child assets in 2006 so that the minimum age at measurement is 36 . We still find that the environmental coefficients are larger than the biological ones. Therefore, these checks provide reassurance that our estimates are not being heavily influenced by children who are too young to have made investment decisions.

\footnotetext{
${ }^{30}$ Sweden is divided into 20 regional county councils. Their main responsibilities are to provide and organize health care and public transportation.
} 


\section{External Validity}

Finally, while our estimates may distinguish between nature and nurture effects among adopted children, there remains the question of whether they identify the relative importance of nature and nurture more generally. Threats to external validity could arise if the adopted children are not representative of children in general or the adoptive and biological parents are not representative of the population of parents. In this section, we examine some of these issues.

\section{Missing Fathers}

As described above, we are missing information on a substantial number of biological parents because the identity of the father was not ascertained at the time of the adoption. To assess whether our results are sensitive to this missing information, we have rerun the main specification using all biological mothers for whom we have information, regardless of whether the information for the biological father is present. The results are presented in columns (5) and (6) of Appendix Table 2. Column (5) presents the results on our main sample when we include only mother characteristics, and Column (6) presents the results for the larger sample, including those with missing fathers. Comparing these estimates, we see that the estimates are quite insensitive to the sample used, suggesting our results may generalize to the population of adoptees more generally. In column (7) we add risk-taking of the adoptive father and we see that the coefficient on this variable is also very similar to that in the baseline specification. 


\section{Reweighting for Generalizability}

As is clear from Table 1, adoptive parents are somewhat positively selected in terms of observables and so may not be representative of parents in general. In addition, biological parents who give their children up for adoption are somewhat negatively selected in terms of observables. To attempt to address these issues, we reweight each observation in the non-adoptees sample to make the comparison families more similar to our sample of adopted children. Because the adopted children are different along two dimensions - their biological parents are negatively selected and their adoptive parents are positively selected-we do the reweighting twice, first to make the non-adoptive parents similar to the adoptive parents and then to make the non-adoptive parents similar to the biological parents of adopted children. When we do so (see Appendix Table 3), we find that the results are quite consistent to those presented earlier, suggesting our results may be generalizable beyond the sample of adoptees. ${ }^{31}$

In addition to the observed differences, there may be unobserved differences between adoptive and other parents. Adoptive parents might invest less or more in their adopted children than other parents. The former could occur if adoptive parents don't treat their children as well as they would if they were biological children; the latter could occur if adoptive parents are "better" parents than average -- adoptive parents must, for

\footnotetext{
31 To calculate weights in the first case, we use a logit model to estimate the probability that a particular parent pair have adopted children using parental characteristics such as birth year, schooling, total assets, indicators for holding risky assets, and earnings. Using the estimated coefficients, we form the propensity score and use this to weight the sample of own-birth children by $\left(\frac{p}{1-p}\right)$, where $p$ is the estimated propensity score. This re-weighting makes the own-birth families similar in observables to the adoptive ones. When we do a weighted regression on the own-birth children, we find coefficients that remain very similar to the un-weighted ones. This is shown in columns (1) and (2) of Appendix Table 3. We take a similar approach here for reweighting the own-child sample to make it similar to the sample of biological parents of adopted children. These estimates are in column (3) of Appendix Table 3. Here the reweighting reduces the estimates slightly for biological mothers and fathers.
} 
instance, be approved before being able to adopt. By definition, we are limited in how much we can assess the unobserved differences between adoptive and other parents. We have, however, verified that the effect of parental risk-taking on biological children in the small number of families with both adoptive and biological children is not statistically different to that of parental risk-taking on biological children in general. ${ }^{32}$ This suggests that there may not be systematic differences in parenting behaviors between biological and adoptive parents. ${ }^{33}$

\section{Conclusion}

A large literature has documented the correlation between parental and child risktaking in terms of portfolio allocations and risk-taking preferences (Charles and Hurst 2003, Dohmen et al. 2012). However, researchers have puzzled over whether these similarities are biologically determined, and how much they are influenced by environmental factors. This paper is able to address this issue using unique data on adoptees in Sweden.

Our main finding is that environmental factors are particularly important in determining the intergenerational transmission of stock market participation. At a minimum, about $2 / 3$ of the intergenerational correlation we observe appears to be driven by environmental factors and only $1 / 3$ can be attributed to biological factors. Once one

\footnotetext{
32 There are 953 own-birth children of adoptive parents in our data. The estimated effects of biological mother and father stock-holding on those children are 0.170 and 0.142 , respectively, which are very similar to those for the full sample of own-birth children.

${ }^{33}$ A proportion of adoptive parents subsequently split up and, thus, the adoptive father may have limited influence on the child. Of our sample of 3275 adoptive children with parents alive in 2000, 2856 have adoptive parents who are still together in 2000. When we allow the effects of parents to differ depending on whether the adoptive parents are still together in 2000 , we find no evidence that the effects differ between the two groups.
} 
conditions on positive financial wealth of parents and children and examines the relationship between the shares of assets held in stocks across generations, the role of environment becomes stronger.

Our findings of strong environmental effects contrast with those from existing work using variation induced by twins that shows little role for shared environmental elements in determining risk-taking in financial markets. Twin studies have found that genes explain around 25-33 percent of the variance in risk-taking in financial markets and that shared environment has little or no influence (Cesarini et al. 2010; Barnea, Cronqvist, and Siegel 2010). One major difference between the two methodologies is that adoption studies estimate regression coefficients and twin studies estimate variance components. This implies that, in our context, twin studies decompose the total variation in risk-taking in financial markets into genes, shared, and non-shared environment, whereas we decompose the intergenerational association into pre- and post-birth factors. Because of this, the estimands of the adoption studies are not directly comparable to the twin-study estimands and comparisons of the regression coefficients to variance decompositions are prone to various methodological hazards. Even so, it is difficult to reconcile our finding of strong environmental effects with the lack of role for shared environment in the twins studies given that shared twin environmental factors should include many of the family influences that we consider likely to be responsible for the nurture effects we find. ${ }^{34}$

Our investigation of the source of environmental effects suggests that controlling for the education, earnings, and wealth of adoptive parents and even of the children has

\footnotetext{
${ }^{34}$ Interestingly, a similar dichotomy is found for entrepreneurship with twin findings suggesting little role for environmental factors but the adoption approach finding environmental factors to be more important than biological ones (Lindquist, Sol, and van Praag 2015).
} 
little impact on the intergenerational stock market participation coefficient. This suggests that the results we observe are not likely just a reflection of some omitted variable related to wealth or income. However, it is difficult to determine which environmental pathways are important. One possibility is that parents provide children with stocks as gifts and this is an important component of the intergenerational correlation. While we can't rule this out without data on gifts, it would clearly be possible for children to sell any such stocks and our results remain even when we consider children aged 36 and older who are presumably sufficiently mature to make these types of financial decisions. Another possibility is that parents provide information about investing and this increases the involvement of their children in the stock market. While this is a likely avenue, we have found that, even conditional on stock market participation, the risky shares of children are correlated with those of their adoptive parents. This raises the possibility that risk preferences of children are shaped by their parents and influenced by their environment rather than truly determined at birth. 


\section{References}

Barber, B. M., \& Odean, T. (2001). Boys will be boys: Gender, overconfidence, and common stock investment. Quarterly journal of Economics, 261-292.

Barnea, A., Cronqvist, H., \& Siegel, S. (2010). Nature or nurture: What determines investor behavior? Journal of Financial Economics, 98(3), 583-604.

Bharadwaj, P., Lundborg, P., \& Rooth, D. O. (2014). Health Endowments and Unemployment during Macroeconomic Crises. Manuscript

Björklund, A., Lindahl, M., \& Plug, E. (2006). The origins of intergenerational associations: Lessons from Swedish adoption data. The Quarterly Journal of Economics, 999-1028.

Black S.E., Devereux, P.J., Lundberg P., and K. Majlesi (2015). Learning to Take Risks? The Effect of Education on Risk-Taking in Financial Markets. NBER Working Paper \#21043.

Calvet, L. E., Campbell, J. Y., \& Sodini, P. (2007). Down or Out: Assessing the Welfare Costs of Household Investment Mistakes. Journal of Political Economy, 115(5), 707-747.

Calvet, L. E., \& Sodini, P. (2014). Twin Picks: Disentangling the Determinants of RiskTaking in Household Portfolios. The Journal of Finance, 69(2), 867-906.

Carling, K., Holmlund, B., \& Vejsiu, A. (2001). Do benefit cuts boost job finding? Swedish evidence from the 1990s. The Economic Journal, 111(474), 766-790.

Cesarini, D., Johannesson, M., Lichtenstein, P., Sandewall, Ö., \& Wallace, B. (2010). Genetic Variation in Financial Decision-Making. The Journal of Finance, 65(5), $1725-$ 1754.

Cesarini, D., Johannesson, M., \& Oskarsson, S. (2014). Pre-birth factors, post-birth factors, and voting: Evidence from Swedish adoption data. American Political Science Review, 108(01), 71-87.

Charles, K. K., \& Hurst, E. (2003). The Correlation of Wealth across Generations. Journal of Political Economy, 111(6).

Chiteji, N. S., \& Stafford, F. P. (1999). Portfolio choices of parents and their children as young adults: Asset accumulation by African-American families. American Economic Review, 377-380.

Dohmen, T., Falk, A., Huffman, D., \& Sunde, U. (2012). The intergenerational transmission of risk and trust attitudes. The Review of Economic Studies, 79(2), 645-677. 
Dreber, A., Apicella, C.L., Eisenberg, D.T.A., Garcia, J.R., Zamore, R.S., 2009. The 7R polymorphism in the dopamine receptor D4 gene (DRD4) is associated with financial risk-taking in men. Evolution and Human Behavior 30, 85-92.

Eckel, C. C. and Grossman, P. J. (2008). Men, Women and Risk Aversion: Experimental Evidence. Vol. 1 of Handbook of Experimental Economics Results. Elsevier, Ch. 113, pp. 1061-1073.

Fagereng, A., Gottlieb, C., \& Guiso, L. (2013). Asset Market Participation and Portfolio Choice over the Life Cycle. Netspar Discussion Paper 26/13.

Fagereng, A., Mogstad, M., \& Rønning, M. (2015). Why do wealthy parents have wealthy children? unpublished manuscript.

Guiso, L., Haliassos, M., \& Jappelli, T. (2001). Household portfolios: An international comparison. Household Portfolios.

Hjalmarsson, R., \& Lindquist, M. J. (2013). The origins of intergenerational associations in crime: lessons from Swedish adoption data. Labour Economics,20, 68-81.

Holmlund, H., Lindahl, M., \& Plug, E. (2011). The causal effect of parents' schooling on children's schooling: a comparison of estimation methods. Journal of Economic Literature, 49(3), 615-651.

Hryshko, D., Luengo-Prado, M. J., \& Sørensen, B. E. (2011). Childhood determinants of risk aversion: The long shadow of compulsory education. Quantitative Economics, 2(1), $37-72$.

Kimball, M. S., Sahm, C. R., \& Shapiro, M. D. (2009). Risk Preferences in the PSID: Individual Imputations and Family Covariation. The American Economic Review, 99(2), 363-368.

Kuhnen, C.M., Chiao, J., 2009. Genetic determinants of financial risk taking. PLoS ONE 4.

Lindahl, Mikael, Evalina Lundberg, Marten Palme, and Emilia Simeonova. 2015. Nature versus Nurture in the Intergenerational Transmission of Health: Lessons from a Large Sample of Adoptees." Unpublished manuscript, May 17.

Lindquist, M. J., Sol, J., \& Van Praag, M. (2015). Why Do Entrepreneurial Parents Have Entrepreneurial Children? Journal of Labor Economics, 33(2), 269-296.

Plug, Erik. 2004. "Estimating the Effect of Mother's Schooling on Children's Schooling Using a Sample of Adoptees." American Economic Review 94 (1): 358-68. 
Plug, Erik, and Wim Vijverberg. 2003. "Schooling, Family Background, and Adoption: Is It Nature or Is It Nurture?” Journal of Political Economy 111 (3): 611-41.

Sacerdote, B. (2007). How large are the effects from changes in family environment? A study of Korean American adoptees. The Quarterly Journal of Economics, 119-157.

Sacerdote, B. (2010). Nature and nurture effects on children's outcomes: What have we learned from studies of twins and adoptees. Handbook of social economics, 1, 1-30.

Socialstyrelsen (2014). Adoption. Handbok för socialtjänstens handläggning av internationella och nationella adoptioner. Falun: 2014.

SOU (1954). Moderskapsförsäkring mm. Socialförsäkringsutredningens betänkande II. Statens Offentliga Utredningar 1954:4. Stockholm: Socialdepartementet.

SOU (1978). Föräldraförsäkring. Betänkande av familjestödsutredningen. Statens Offentliga Utredningar 1978:39. Stockholm: Socialdepartementet.

SOU (2009). Modernare adoptionsregler. Betänkande av 2008 års adoptionsutredning. Statens Offentliga Utredningar 2009:61. Stockholm: Socialdepartementet.

Thörnqvist, T., \& Vardardottir, A. (2014). Bargaining over Risk: The Impact of Decision Power on Household Portfolios. Manuscript. 
Table 1. Summary Statistics

\begin{tabular}{|c|c|c|c|c|}
\hline \multirow[b]{4}{*}{ Financial assets* } & \multicolumn{2}{|c|}{ Own-birth children } & \multicolumn{2}{|c|}{ Adopted children } \\
\hline & Mean & SD & Mean & SD \\
\hline & \multicolumn{4}{|c|}{ Children } \\
\hline & 101,749 & $1,163,991$ & 102,160 & 614,863 \\
\hline Financial wealth dummy** & 0.69 & 0.46 & 0.61 & 0.49 \\
\hline Risky asset holding (including mutual funds) $* * *$ & 0.57 & 0.50 & 0.49 & 0.50 \\
\hline Stock holding $* * *$ & 0.26 & 0.44 & 0.23 & 0.42 \\
\hline Stock share (cond. on positive financial wealth) & 0.15 & 0.29 & 0.16 & 0.31 \\
\hline Stock share (cond. on stock market participation) & 0.40 & 0.35 & 0.43 & 0.37 \\
\hline Age in 2000 & 32.50 & 8.08 & 34.91 & 6.61 \\
\hline Years of schooling & 12.42 & 2.17 & 11.94 & 2.07 \\
\hline Female & 0.49 & 0.50 & 0.48 & 0.50 \\
\hline \multirow[t]{2}{*}{ Observations } & \multicolumn{2}{|c|}{$2,077,479$} & \multicolumn{2}{|c|}{3,275} \\
\hline & \multicolumn{4}{|c|}{ Biological parents } \\
\hline Financial assets, mother* & 217,700 & $4,150,615$ & 81,770 & 273,032 \\
\hline Financial wealth dummy, mother** & 0.77 & 0.42 & 0.49 & 0.50 \\
\hline Financial assets, father* & 323,195 & $2,417,708$ & 156,992 & 681,774 \\
\hline Financial wealth dummy, father** & 0.78 & 0.41 & 0.51 & 0.50 \\
\hline Risky asset holding (including mutual funds), mother*** & 0.62 & 0.49 & 0.35 & 0.48 \\
\hline Risky asset holding (including mutual funds), father*** & 0.64 & 0.48 & 0.37 & 0.48 \\
\hline Stock holding, mother*** & 0.30 & 0.46 & 0.14 & 0.35 \\
\hline Stock holding, father*** & 0.43 & 0.49 & 0.23 & 0.42 \\
\hline Stock share, mother (cond. on positive financial wealth) & 0.11 & 0.24 & 0.09 & 0.24 \\
\hline Stock share, mother (cond. on stock market participation) & 0.29 & 0.31 & 0.33 & 0.35 \\
\hline Stock share, father (cond. on positive financial wealth) & 0.19 & 0.30 & 0.18 & 0.32 \\
\hline Stock share, father (cond. on stock market participation) & 0.34 & 0.33 & 0.40 & 0.38 \\
\hline Age in 2000, mother & 58.87 & 9.14 & 57.44 & 7.89 \\
\hline Age in 2000, father & 61.63 & 9.51 & 60.42 & 8.42 \\
\hline Years of schooling, mother & 10.77 & 2.96 & 9.79 & 2.49 \\
\hline \multirow[t]{2}{*}{ Years of schooling, father } & 10.59 & 3.15 & 9.67 & 2.66 \\
\hline & \multicolumn{4}{|c|}{ Adoptive parents } \\
\hline Financial assets, mother* & & & 323,750 & 911,938 \\
\hline Financial wealth dummy, mother** & & & 0.85 & 0.36 \\
\hline Financial assets, father* & & & 463,976 & $2,668,195$ \\
\hline Financial wealth dummy, father** & & & 0.87 & 0.34 \\
\hline Risky asset holding (including mutual funds), mother*** & & & 0.66 & 0.47 \\
\hline Risky asset holding (including mutual funds), father*** & & & 0.71 & 0.45 \\
\hline Stock holding, mother*** & & & 0.34 & 0.47 \\
\hline Stock holding, father*** & & & 0.47 & 0.50 \\
\hline Stock share, mother (cond. on positive financial wealth) & & & 0.11 & 0.23 \\
\hline Stock share, mother (cond. on stock market participation) & & & 0.27 & 0.30 \\
\hline Stock share, father (cond. on positive financial wealth) & & & 0.17 & 0.28 \\
\hline Stock share, father (cond. on stock market participation) & & & 0.31 & 0.32 \\
\hline Age in 2000, mother & & & 66.47 & 8.25 \\
\hline Age in 2000, father & & & 68.86 & 8.39 \\
\hline Years of schooling, mother & & & 10.50 & 3.12 \\
\hline Years of schooling, father & & & 10.81 & 3.35 \\
\hline
\end{tabular}

Notes: * All monetary values are reported in Swedish Krona on December 31, 2000. At the time, the exchange rate was $1 \mathrm{USD}=9.42 \mathrm{SEK}$.

** A dummy, taking a value of 1 if financial wealth is positive

*** A dummy, taking a value of 1 if the individual participates 


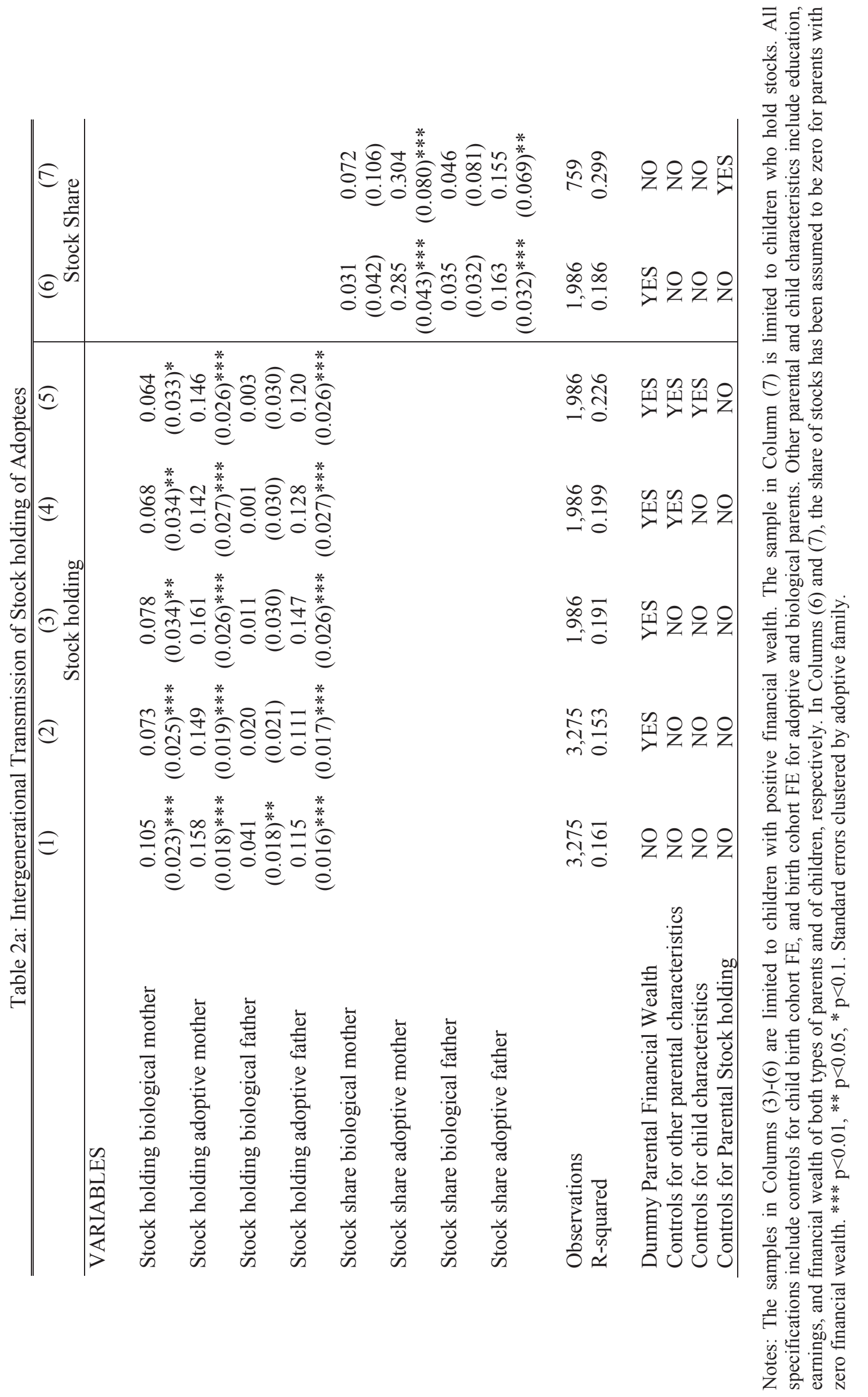




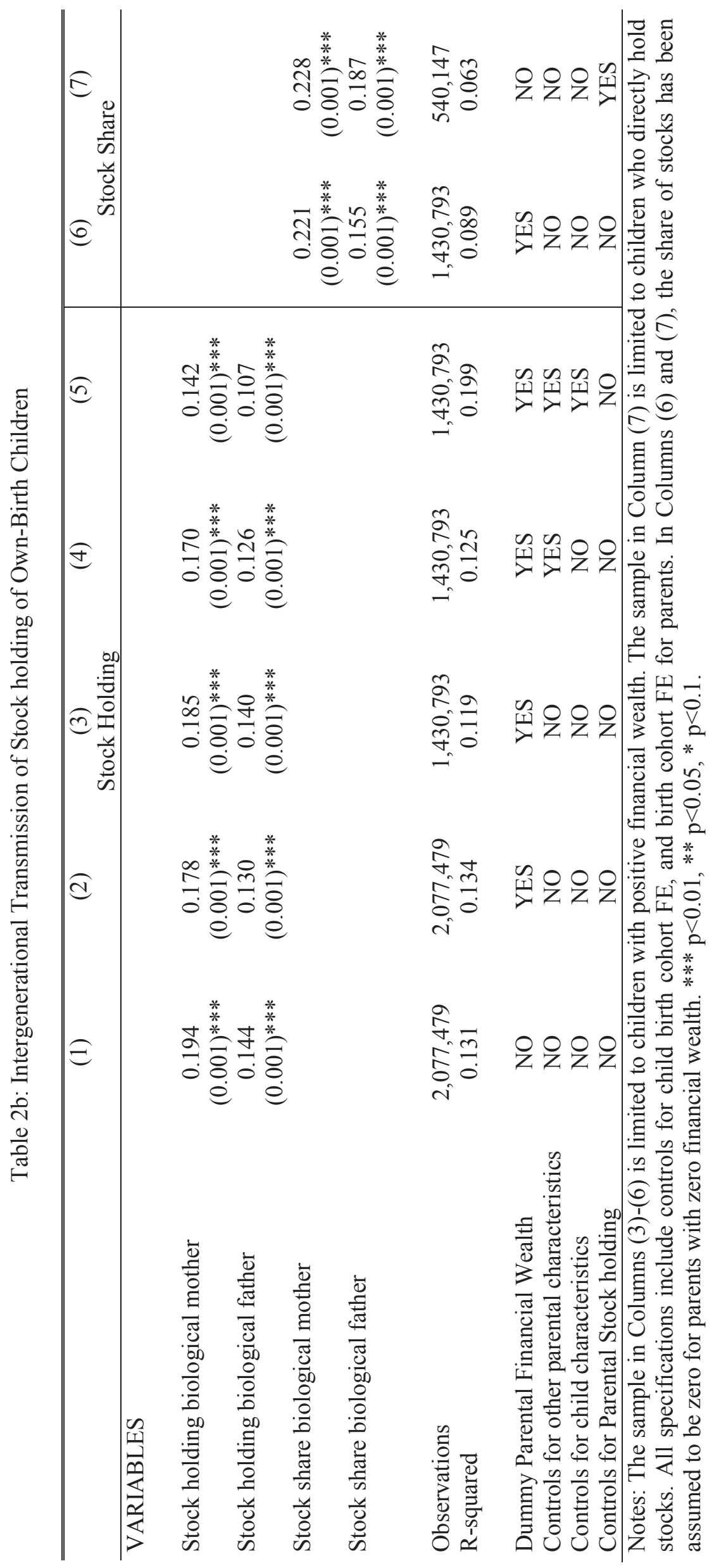




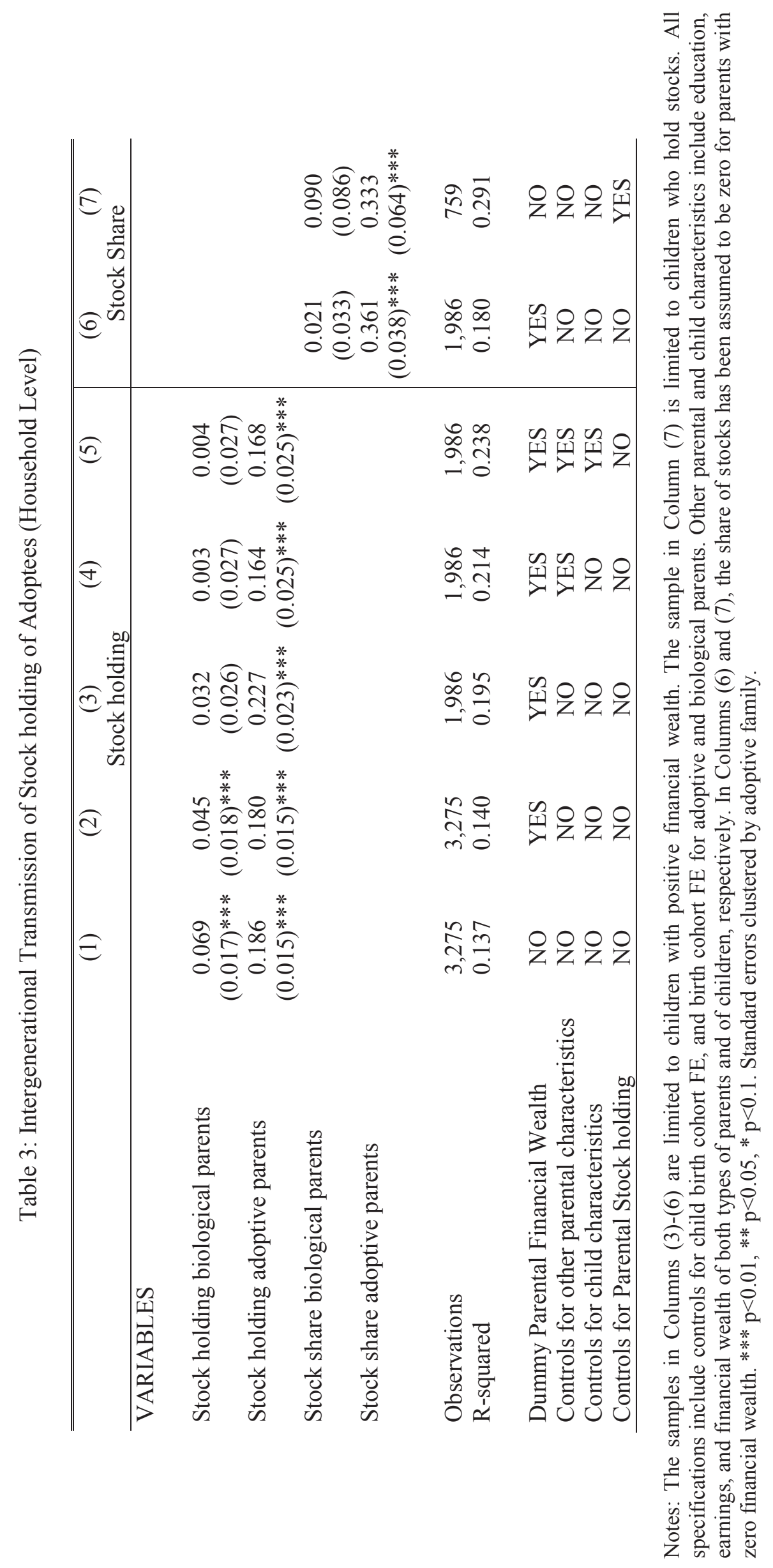




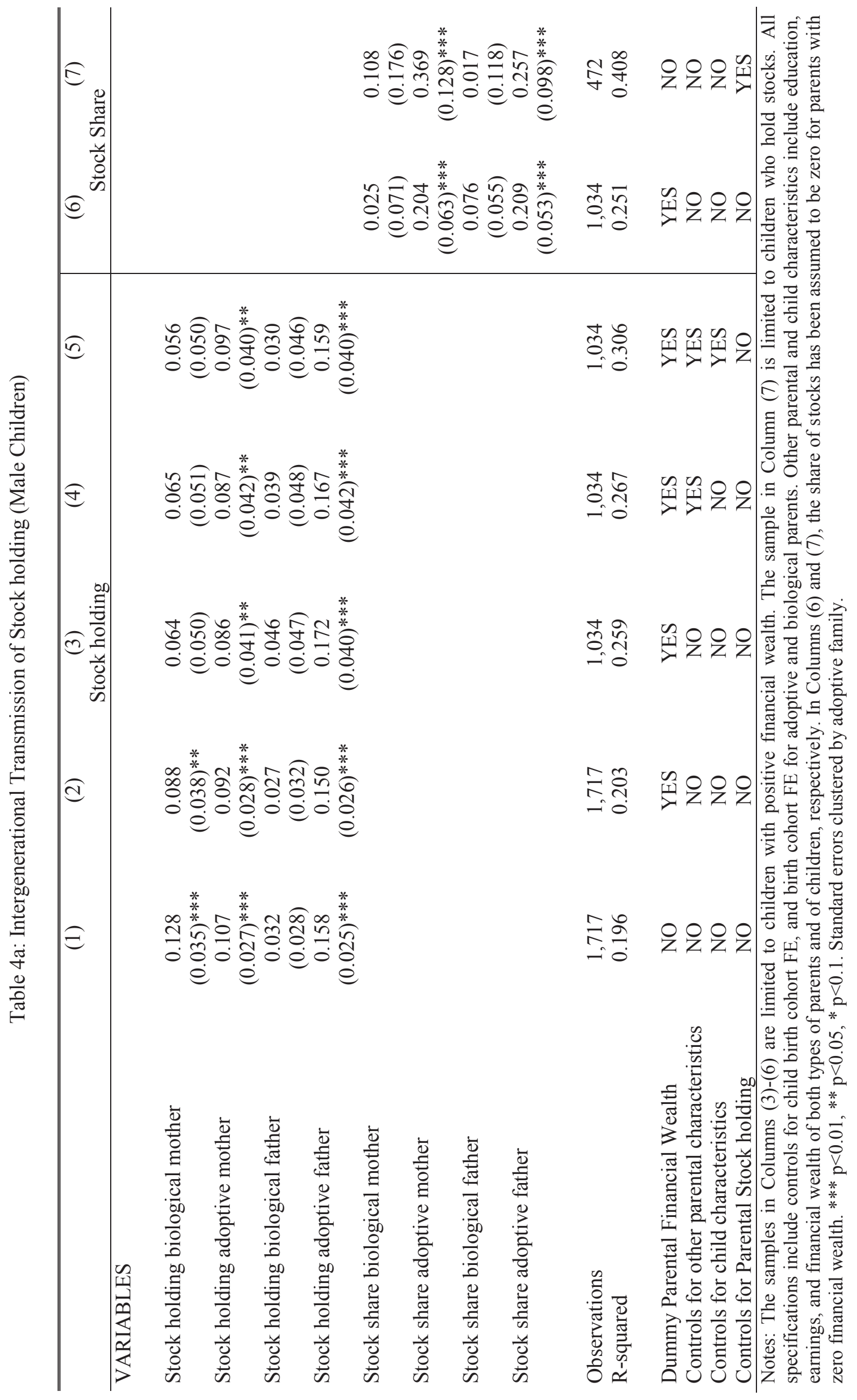




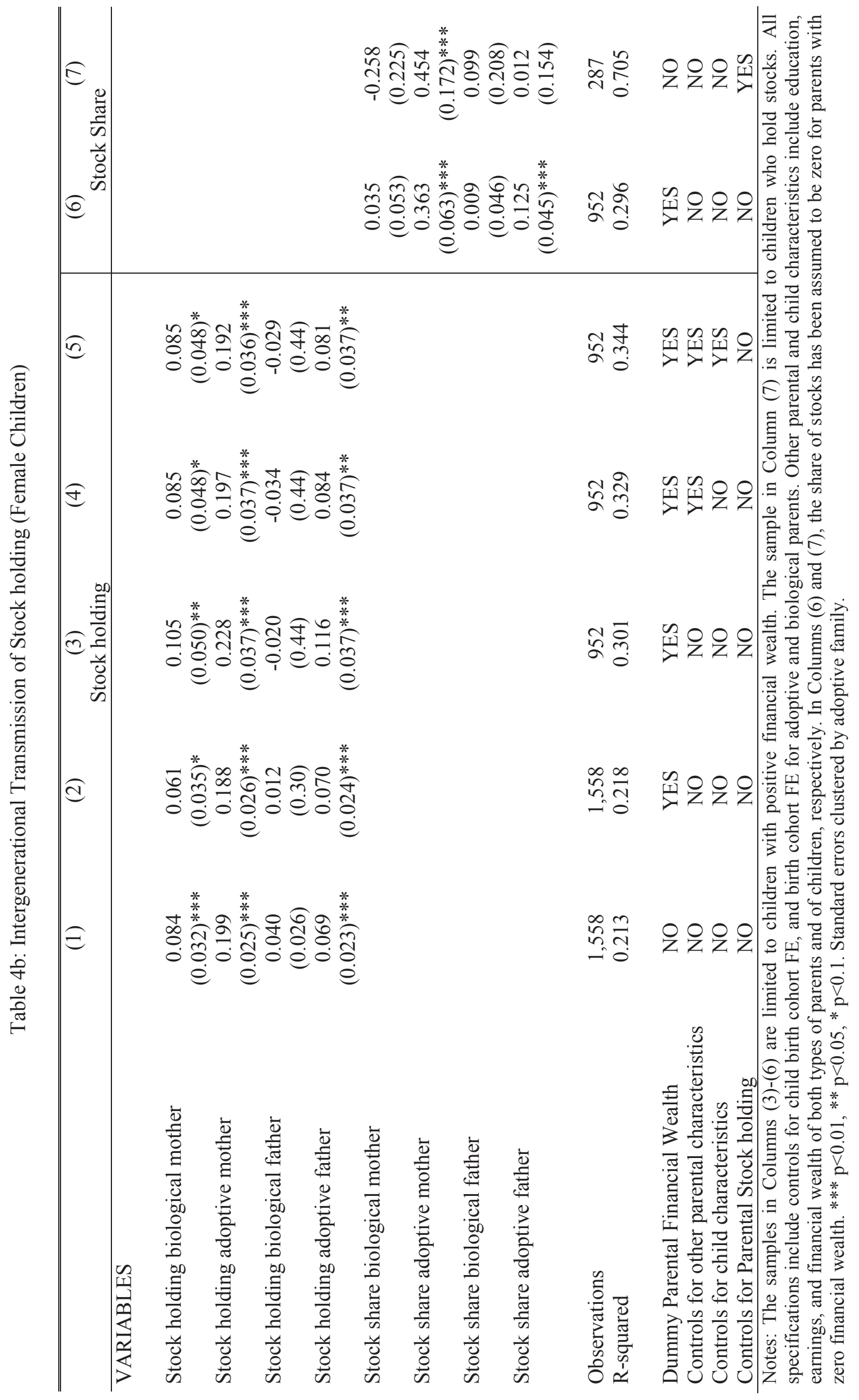




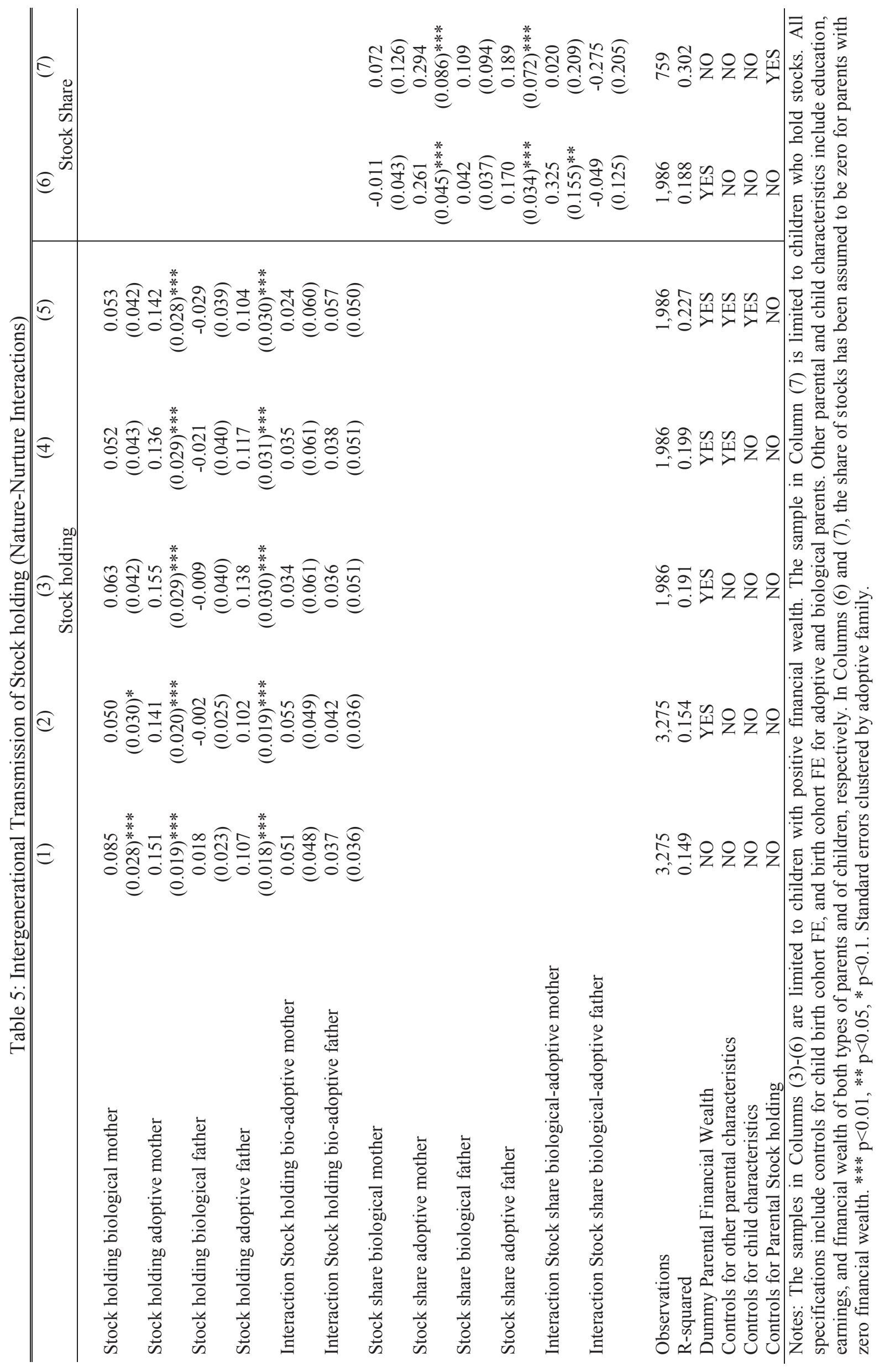




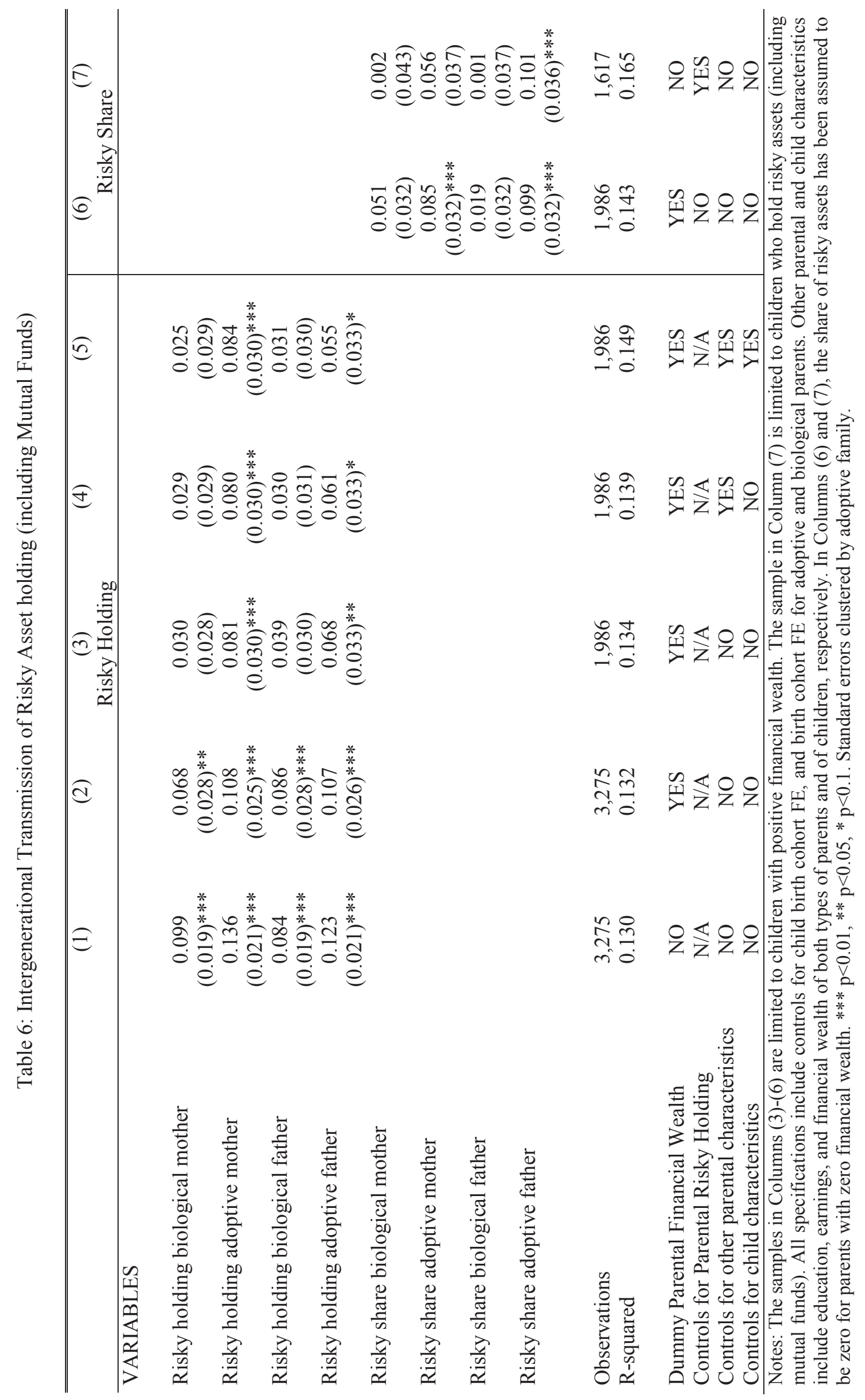




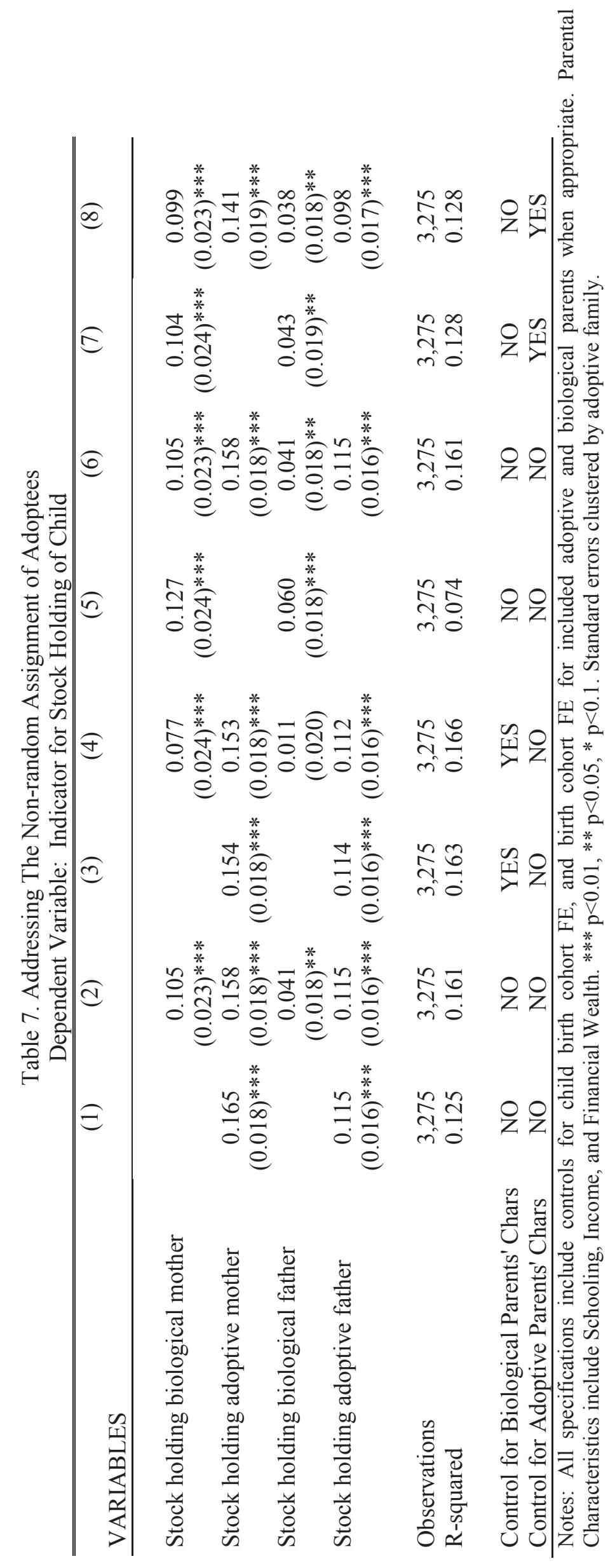




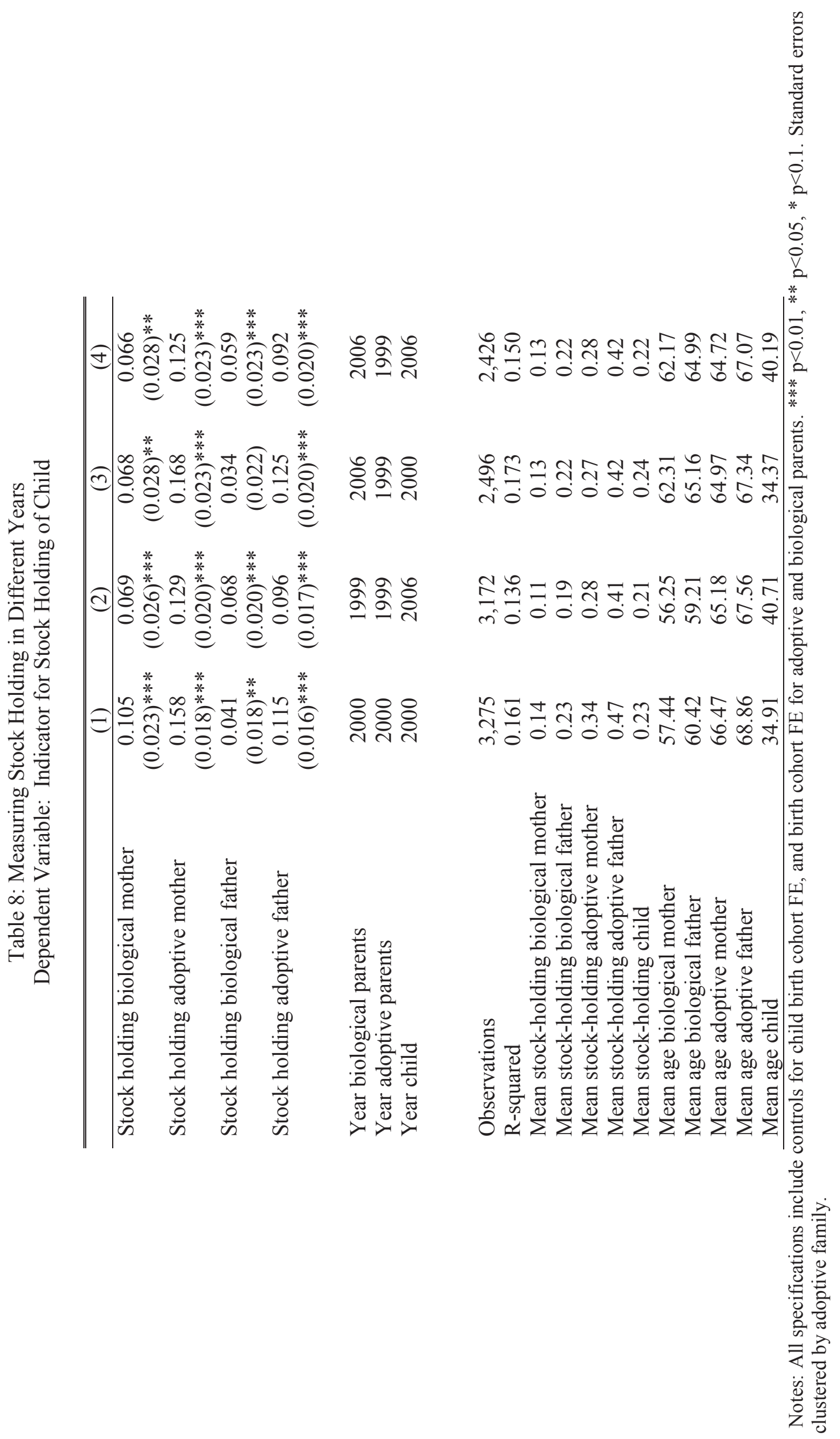




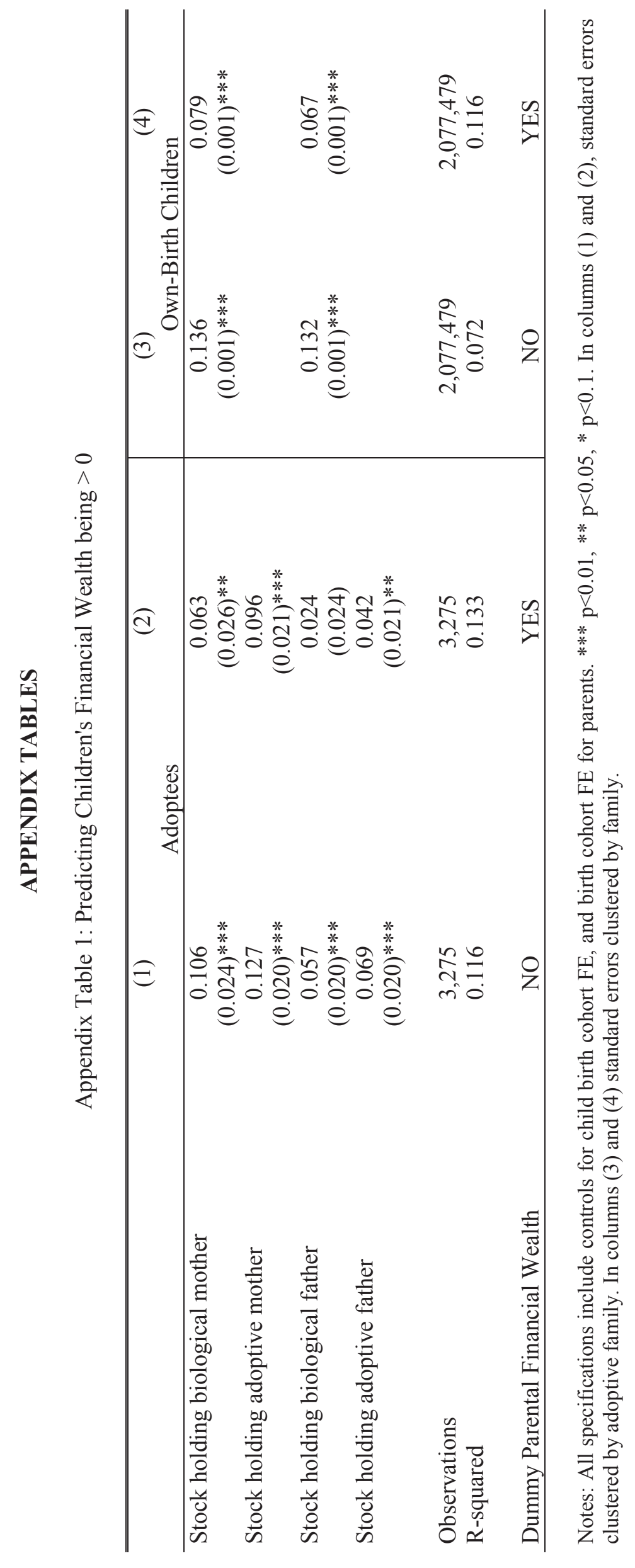




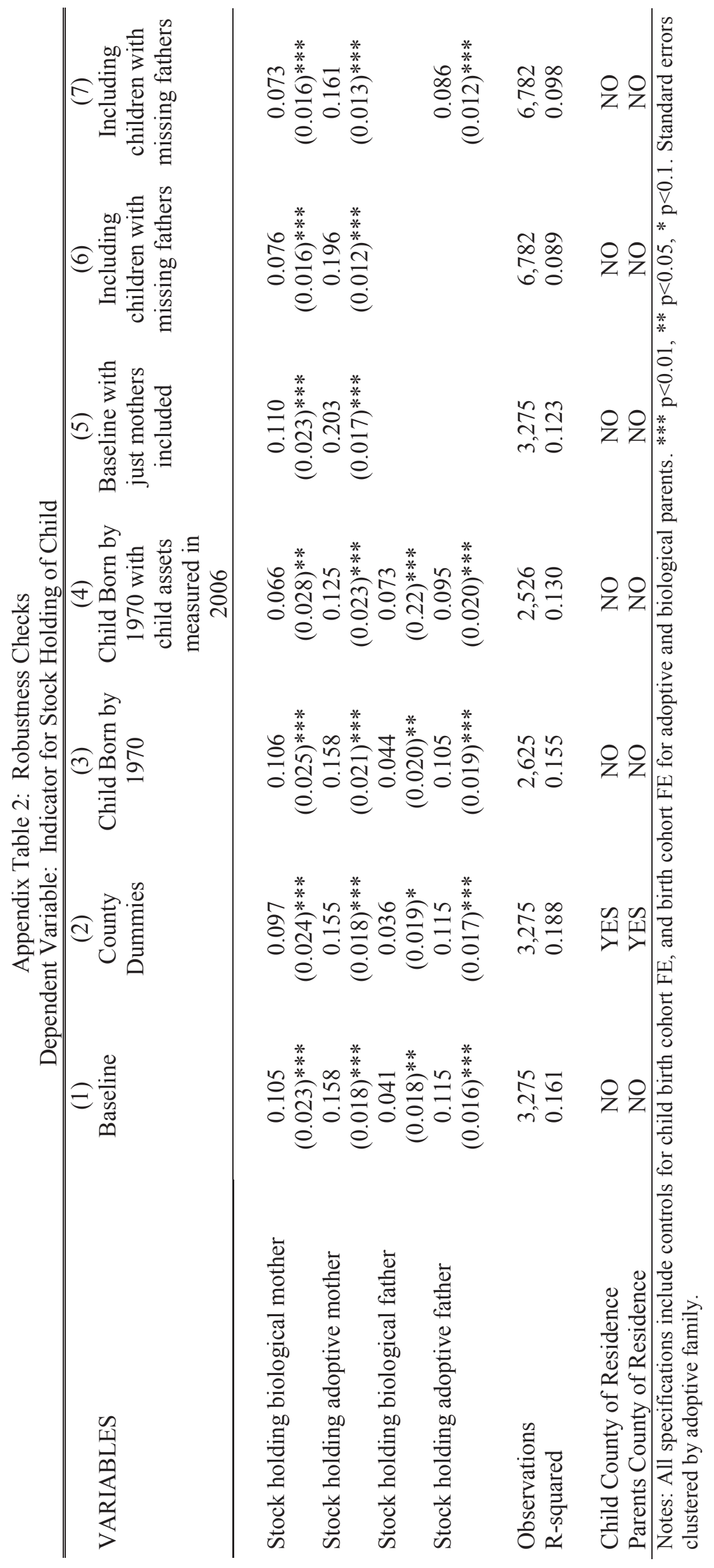




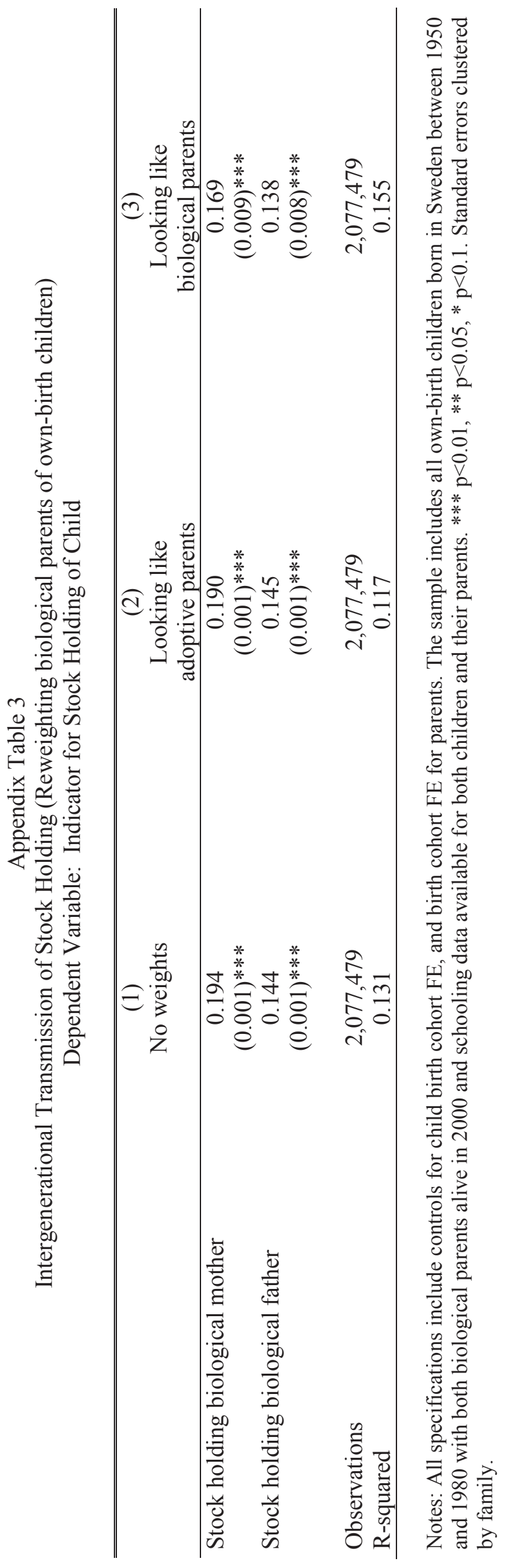





\title{
On The Origins of Risk-Taking in Financial Markets
}

\author{
SANDRA E. BLACK | PAUL J. DEVEREUX | PETTER LUNDBORG | KAVEH MAJLESI
}

Risk-taking in financial markets is highly correlated between parents and their children; however, little is known about the extent to which these relationships are genetic or determined by environmental factors. We use data on stock market participation of Swedish adoptees and relate this to the investment behavior of both their biological and adoptive parents. We find that stock market participation of parents increases that of children by about $34 \%$ and that both pre-birth and post-birth factors are important. However, once we condition on having positive financial wealth, we find that nurture has a much stronger influence on risk-taking by children, and the evidence of a relationship between stock-holding of biological parents and their adoptive children becomes weaker. We find similar results when we study the share of financial wealth that is invested in stocks. This suggests that a substantial proportion of the transmission of risk behavior from parents to children is environmentally determined.

JEL Codes: G11; J13; J62

Keywords: Intergenerational mobility, nature versus nurture, portfolio allocation

\section{THE KNUT WICKSELL CENTRE FOR FINANCIAL STUDIES}

The Knut Wicksell Centre for Financial Studies conducts cutting-edge research in financial economics and related academic disciplines. Established in 2011, the Centre is a collaboration between Lund University School of Economics and Management and the Research Institute of Industrial Economics (IFN) in Stockholm. The Centre supports research projects, arranges seminars, and organizes conferences. A key goal of the Centre is to foster interaction between academics, practitioners and students to better understand current topics related to financial markets. 